\title{
Bacillus licheniformis PR2 Controls Fungal Diseases and Increases Production of Jujube Fruit under Field Conditions
}

\author{
Jun-Hyeok Kwon ${ }^{1,+}{ }^{\oplus}$, Sang-Jae Won ${ }^{1,+}$, Jae-Hyun Moon ${ }^{1}$, Uk Lee ${ }^{2}$, Yun-Serk Park ${ }^{3}$, Chaw Ei Htwe Maung ${ }^{4}$, \\ Henry B. Ajuna ${ }^{1}$ and Young Sang Ahn ${ }^{1, *(D)}$ \\ 1 Department of Forest Resources, College of Agriculture and Life Sciences, Chonnam National University, \\ Gwangju 61186, Korea; wg6102@naver.com (J.-H.K.); lazyno@naver.com (S.-J.W.); \\ mjh132577@naver.com (J.-H.M.); ajunahenry@mmu.ac.ug (H.B.A.) \\ 2 Division of Forest Special Products, National Institute of Forest Science, Suwon 16631, Korea; rich26@korea.kr \\ 3 Institute of Environmentally-Friendly Agriculture, Chonnam National University, Gwangju 61186, Korea; \\ prunea@naver.com \\ 4 Division of Agricultural and Biological Chemistry, Institute of Environmentally-Friendly Agriculture, College \\ of Agriculture and Life Sciences, Chonnam National University, Gwangju 61186, Korea; \\ chaweihtwemaung@gmail.com \\ * Correspondence: ysahn@jnu.ac.kr; Tel.: +82-62-530-2081 \\ + Jun-Hyeok Kwon and Sang-Jae Won contributed equally to this work.
}

Citation: Kwon, J.-H.; Won, S.-J.; Moon, J.-H.; Lee, U.; Park, Y.-S.; Maung, C.E.H.; Ajuna, H.B.; Ahn, Y.S. Bacillus licheniformis PR2 Controls Fungal Diseases and Increases Production of Jujube Fruit under Field Conditions. Horticulturae 2021, 7, 49. https://doi.org/10.3390/ horticulturae7030049

Academic Editors

Alessandra Francini and Stefania M. Mang

Received: 6 January 2021

Accepted: 10 March 2021

Published: 12 March 2021

Publisher's Note: MDPI stays neutral with regard to jurisdictional claims in published maps and institutional affiliations.

Copyright: (c) 2021 by the authors. Licensee MDPI, Basel, Switzerland. This article is an open access article distributed under the terms and conditions of the Creative Commons Attribution (CC BY) license (https:// creativecommons.org/licenses/by/ $4.0 /)$.

\begin{abstract}
There is a growing interest in using biocontrol agents to control fungal diseases and increase the production of jujube fruit (Zizyphus jujua Miller var. inermis Rehder). The purpose of this study was to use Bacillus licheniformis PR2 to inhibit fungal diseases and promote fruit production in jujube orchards. B. licheniformis PR2 secreted $92.4 \mathrm{unit} / \mathrm{mL}$ of chitinase, which inhibited fungal phytopathogens through hyphal alterations with swelling and bulbous structures. B. licheniformis PR2 also inhibited mycelial growths of fruit fungal pathogens Botrytis cinerea, Colletotrichum gloeosporioides, and Phytophthora nicotianae by $81.3 \%, 60.1 \%$, and $67.0 \%$, respectively. B. licheniformis PR2 increased jujube fruit yield by $17.9 \mathrm{~kg} /$ tree by reducing rotting damage caused by fungal pathogens, with a yield 3.2 times higher than that achieved by the control without PR2 treatment. In addition, B. licheniformis PR2 produced auxin, which promoted cell division after flower fertilization, thus increasing fruit length and diameter by 1.2-fold compared to those of the control. These results confirmed that eco-friendly B. licheniformis PR2 could effectively control fungal diseases in jujube orchards and improve its fruit size and yield.
\end{abstract}

Keywords: antagonistic bacteria; biocontrol agent; lytic enzyme; fungal pathogens; auxin; fruit yield; jujube cultivation

\section{Introduction}

The fruit of the jujube (Zizyphus jujua Miller var. inermis Rehder) is known to contain several components such as phenolic compounds, minerals, polysaccharides, vitamin complexes, and dietary fiber with high nutritional or health-promoting values [1-3]. Several of these substances are biologically active compounds known to have positive effects on human health, such as antioxidative and immunoregulatory activities and heart disease preventing effects [1,3]. There are around 170 species of jujube. They grow primarily in regions with warm climates [4]. Jujube fruit has thin skin and high sugar and moisture contents. Because of these features, it is highly susceptible to fruit cracking and fungal diseases [5]. There are 30 major fungal pathogens, including Botrytis cinerea, Colletotrichum gloeosporioides, and Phytophthora nicotianae that cause diseases of jujube fruits (see Figure 1D) [5,6]. Fungal diseases can destroy crops and render them unsellable. Thus, the use of fungicides is arguably the most important disease management method in orchard crops [7]. However, most fungal diseases are difficult to eradicate and disease outbreaks can continue to occur across several growing seasons. They often originate 
from spores that have lain dormant over winter. In addition, regular use of fungicides can pose a risk to the environment due to residues that persist in soils or migrate into waterways [8-11]. Fungicide pollution can adversely affect the health of terrestrial and aquatic ecosystems. For instance, long-term use of copper-based fungicides has resulted in copper accumulations in the soil, harming soil organisms such as earthworms and microorganisms and posing potential risks to long-term soil fertility [11,12]. To ensure crop sustainability, growers must strike a balance between controlling fungal disease risks and protecting ecosystems. This need is driven by increasing community expectations for governments and industries to protect environmental assets during their operations [13]. In addition, from a marketing perspective, consumers are increasingly pressuring agricultural industries to demonstrate environmental consciousness when performing food production activities [14].

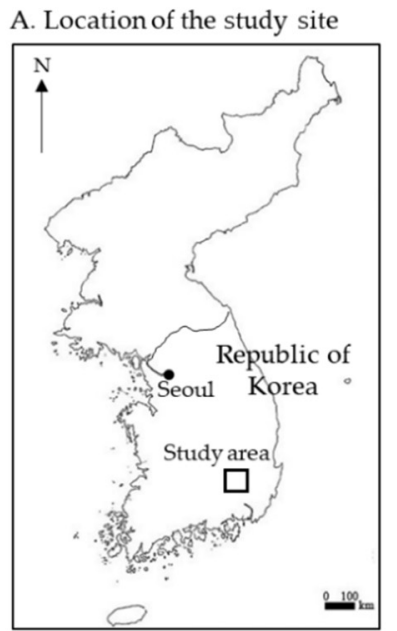

B. Jujube trees in experimental site

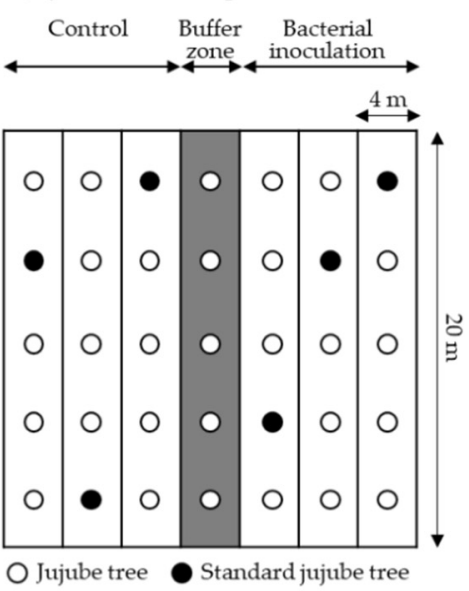

C. Application of bacterial inoculation (left) and bacterial fermentation tank (right)

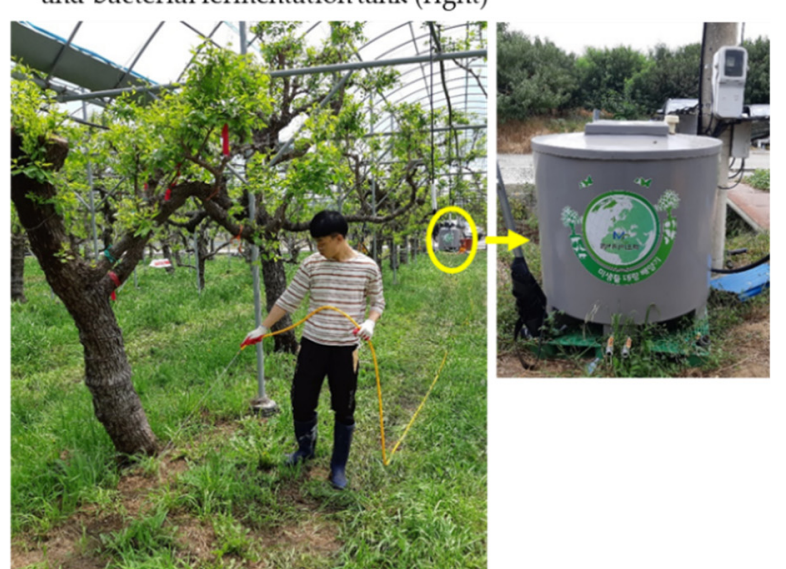

D. Fungal diseases in jujube fruit
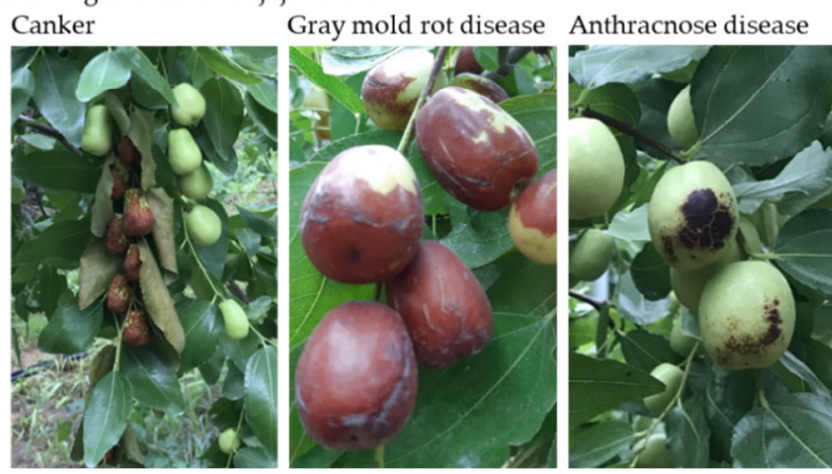

Phytophthora rot disease

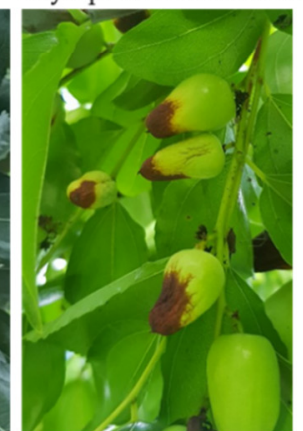

Figure 1. (A) Jujube orchard study location; (B) Jujube trees in experimental site; (C) Application of bacterial inoculation (left) and bacterial fermentation tank (right); (D) Jujube fruit fungal diseases, canker disease, gray mold rot caused by Botrytis cinerea, anthracnose caused by Colletotrichum gloeosporioides, and phytophthora fruit rot caused by Phytophthora nicotianae.

The risk to the environment posed by the use of fungicides in crop production has received relatively little research attention compared to studies devoted to other types of agrochemicals such as insecticides and herbicides. However, plant growthpromoting rhizobacteria (PGPR) have attracted the attention of many researchers because they can inhibit the occurrence of fungal diseases and simultaneously increase the productivity of crops $[5,15,16]$. PGPR include a variety of genera, including Azotobacter spp., Azospirillum spp., Pseudomonas spp., Lysobacter spp., and Bacillus spp. that help plants both directly and indirectly $[16,17]$. Direct effects of PGPR include increasing soil nutrient content by fixing atmospheric nitrogen and solubilizing phosphorus [16-22] as well as enhancing root development by phytohormone auxin secretion $[5,16,17,21-28]$. In particular, auxin can promote root hair development and improve nutrient uptake $[5,16,17,21-28]$, thereby 
enhancing the photosynthetic activities of plants $[16,29,30]$. The improved photosynthetic activity can lead to accumulations of various compounds, including sugar in the fruit, thus enhancing fruit yield and quality [16,29]. Meanwhile, PGPR can indirectly boost plant health by limiting mycelial growths of fungal pathogens by promoting structural decomposition of fungal hyphae and enhancing immunity using lytic enzymes [5,16,27,28,31,32]. Chitinases, in particular, can effectively suppress the occurrence of fungal diseases by disassembling chitins that make up most of the fungal hyphae and by inducing abnormal growth such as expansion, decomposition, and folding of the fungus $[5,27,28]$.

When applying agricultural chemicals, it is inevitable that farmers' sprays will drift beyond their targets. Much of the lost chemical will enter local soils and water resources, causing adverse environmental effects [8,9,11,12]. Many researchers have used PGPR instead of fungicides in the attempt to control fungal diseases $[5,15,27,28]$ and improve yields of fruits such as raspberry, apple, strawberry, and cherry [5,18-20,33]. Kwon et al. [5] have used Lysobacter antibioticus HS124 to control major fungal diseases that severely damaged jujube fruit production in orchards, thus improving fruit production and quality. L. antibioticus HS124 is known to secrete chitinase, which inhibits the growth of B. dothidea, B. cinerea, and C. gloeosporioides and increases fruit yield by 2.9 times compared to control [5]. However, farmers demand antagonistic bacteria that can control fungal diseases and improve cultivated jujube fruit production and quality more effectively than L. antibioticus HS124. Therefore, the objective of this study was to investigate the effects of using Bacillus licheniformis PR2 as a candidate biocontrol agent to prevent fruit fungal diseases, particularly diseases caused by B. cinerea, C. gloeosporioides, and P. nicotianae, thus increasing the production of jujube fruits.

\section{Materials and Methods}

\subsection{Antagonistic Bacteria Growth}

B. licheniformis PR2, a bacterial strain used in this study, was obtained from Purne Inc. (Jangseong, Jeonnam Province, Korea). It was originally isolated from a land cultivated with pepper. These bacteria were subcultured in $30 \mathrm{~g} / \mathrm{L}$ tryptic soy broth (TSB) medium (Daejung Chemicals, Siheung, Korea), mixed with $20 \mathrm{~g} / \mathrm{L}$ agar (Daejung Chemicals), and $1 \mathrm{~L}$ distilled water, and incubated at $30^{\circ} \mathrm{C}$ for 3 days. Then, a single colony from the fresh culture medium was pre-inoculated into TSB (TSB, $30 \mathrm{~g} / \mathrm{L}$; distilled water, $1 \mathrm{~L}$ ) and cultured for 3 days. Thereafter, $100 \mu \mathrm{L}$ of a pre-inoculated B. licheniformis PR2 culture $\left(10^{7}\right.$ colonyforming unit (CFU)/mL) was inoculated into $100 \mathrm{~mL}$ pink casitone (PC) broth containing $3 \mathrm{~g} / \mathrm{L}$ of fertilizer (Purne), $0.2 \mathrm{~g} / \mathrm{L}$ of $\mathrm{MgSO}_{4} \cdot 7 \mathrm{H}_{2} \mathrm{O}$ (Shimakyu's Pure Chemicals, Osaka, Japan), $0.2 \mathrm{~g} / \mathrm{L}$ of $\mathrm{KH}_{2} \mathrm{PO}_{4}$ (Daejung Chemicals), $0.1 \mathrm{~g} / \mathrm{L}$ of $\mathrm{NaCl}$ (Daejung Chemicals), $3 \mathrm{~g} / \mathrm{L}$ of sucrose (Beksul, CJ CheilJedang, Incheon, Korea), $0.6 \mathrm{~g} / \mathrm{L}$ of chitin powder (Purne), $0.6 \mathrm{~g} / \mathrm{L}$ of yeast extract (Daejung Chemicals), $3 \mathrm{~g} / \mathrm{L}$ of pancreatic digest of casein (Neogen, Lansing, MI, USA), and $1 \mathrm{~L}$ of distilled water. This mixture was stirred at $130 \mathrm{rpm}$ at $30{ }^{\circ} \mathrm{C}$ for 10 days. The culture was collected daily and each collected sample was inoculated onto a PC agar medium to count CFUs.

\subsection{Production of Chitinase by B. licheniformis PR2}

To examine chitinase activity at different incubation times, B. licheniformis PR2 was cultured in PC broth at $30^{\circ} \mathrm{C}$ for 10 days in a shaking incubator at $130 \mathrm{rpm}$. Samples were collected daily and centrifuged at 10,000 rpm for $10 \mathrm{~min}$ to obtain supernatants. The supernatants were investigated for chitinase activity on each sampling day. Chitinase activity was measured following the method of Lingappa and Lockwood [34] using a solution of $50 \mu \mathrm{L}$ of $B$. licheniformis PR2 supernatant, $450 \mu \mathrm{L}$ of $0.2 \mathrm{M}$ sodium acetate buffer ( $\mathrm{pH} 5.0$ ), and $500 \mu \mathrm{L}$ of $0.5 \%$ colloidal chitin. After $1 \mathrm{~h}$ incubation at $37^{\circ} \mathrm{C}$, the reaction was terminated by adding $200 \mu \mathrm{L}$ of $1 \mathrm{~N} \mathrm{NaOH}$ (Yakuri Pure Chemicals, Kyoto, Japan). The mixture was centrifuged at $12,000 \mathrm{rpm}$ for $10 \mathrm{~min}$ at $4{ }^{\circ} \mathrm{C}$ to remove colloidal chitin. Then, $750 \mu \mathrm{L}$ of supernatant was mixed with $1 \mathrm{~mL}$ Schales' reagent $(0.5 \mathrm{M}$ sodium carbonate and $1.5 \mathrm{mM}$ potassium ferricyanide). After adding $250 \mu \mathrm{L}$ of distilled water and 
reacting at $100{ }^{\circ} \mathrm{C}$ for $15 \mathrm{~min}$, the amount of reducing sugar was quantitatively analyzed at $420 \mathrm{~nm}$ using an ultraviolet (UV) spectrometer (Shimadzu, Kyoto, Japan). One unit of enzyme activity was determined as the quantity of enzyme that released $1 \mu \mathrm{mol}$ of $\mathrm{N}$-acetyl-glucosamine per hour at $37^{\circ} \mathrm{C}$. Each experiment was conducted in triplicate and repeated three times.

\subsection{Inhibition of Fungal Pathogens by B. licheniformis PR2}

The following pathogenic fungi: B. cinerea, C. gloeosporioides, and P. nicotianae, used in this study, were obtained from Korea Agricultural Culture Collection. These three fungi were cultured on potato dextrose agar (PDA) at $25{ }^{\circ} \mathrm{C}$ for 7 days. The antagonistic activities of $B$. licheniformis PR2 against the three fungi were investigated by the dual culture method. PDA agar plates were inoculated on one side with $5 \mathrm{~mm}$ of phytopathogenic fungi, and streaked with $B$. licheniformis PR2 at a distance of $4 \mathrm{~cm}$ from the fungal pathogen on the same plate, and the plates incubated at $25^{\circ} \mathrm{C}$. Phytopathogenic fungi were incubated for different lengths of time depending on the fungal pathogen: B. cinerea, 5 days; C. gloeosporioides, 6 days; P. nicotianae, 7 days. For the controls, plates inoculated with respective the fungal pathogen without $B$. licheniformis PR2 were used. The inhibition of fungal growth by $B$. licheniformis PR2 was measured using the following formula: inhibition $(\%)=[(\alpha-\beta) / \alpha] \times 100$, where $\alpha$ was the radial growth of the phytopathogenic fungus on the control plate and $\beta$ was the radial growth of fungus on the dual-culture plate. For the treatment group, radial growth was measured from the source of fungus inoculum towards the bacteria colony. The experiments for fungal growth inhibition were performed in triplicate. To examine the effects of $B$. licheniformis PR2 on hyphal morphologies of fungal pathogens, a small piece of mycelium taken from the border of fungal pathogens colony inhibited by B. licheniformis PR2 was used. The deformation of hyphal structures were observed under a light microscope (Olympus BX41TF, Tokyo, Japan).

\subsection{Production of Indole-3-Acetic Acid (IAA) by B. licheniformis PR2}

The amount of IAA production by B. licheniformis PR2 was quantified using Salkowski's method [35] with UV spectrometers. B. licheniformis PR2 was cultured in a medium containing $0.1 \mathrm{~g} / \mathrm{L}$ crab shell powder (Purne, Jangseong, Korea), $0.2 \mathrm{~g} / \mathrm{L} \mathrm{Na}_{2} \mathrm{HPO}_{4}$ (Daejung chemicals, Siheung, Korea), $0.1 \mathrm{~g} / \mathrm{L} \mathrm{KH}_{2} \mathrm{PO}_{4}$ (Daejung chemicals, Siheung, Korea), $0.5 \mathrm{~g} / \mathrm{L}$ $\mathrm{NaCl}$ (Daejung chemicals, Siheung, Korea), $0.1 \mathrm{~g} / \mathrm{L} \mathrm{NH}_{4} \mathrm{Cl}$ (Yakuri pure chemicals, Kyoto, Japan), $0.05 \mathrm{~g} / \mathrm{L} \mathrm{MgSO}_{4} 7 \mathrm{H}_{2} \mathrm{O}$ (Shimakyu's pure chemicals, Osaka, Japan), $0.05 \mathrm{~g} / \mathrm{L} \mathrm{CaCl}_{2}$ $2 \mathrm{H}_{2} \mathrm{O}$ (Daejung chemicals, Siheung, Korea), $0.01 \mathrm{~g} / \mathrm{L}$ yeast extract (Purne, Jangseong, Korea), and $0.1 \mathrm{~g} / \mathrm{L}$ L-tryptophan (Junsei chemical, Tokyo, Japan). The broth was inoculated with $1 \mathrm{~mL} / \mathrm{L}$ of $B$. licheniformis PR2 culture $\left(10^{7} \mathrm{CFU} / \mathrm{mL}\right)$ and cultured at $130 \mathrm{rpm}$ in a shaking incubator at $30{ }^{\circ} \mathrm{C}$ for 10 days. To quantify IAA, samples were collected daily for 10 days. For quantification, $1 \mathrm{~mL}$ of supernatant was collected by centrifuging the sample at 12,000 rpm for $10 \mathrm{~min}$ at $4{ }^{\circ} \mathrm{C}$. The collected supernatant was mixed with $2 \mathrm{~mL}$ of Salkowski's reagent and $0.2 \mathrm{~mL}$ phosphoric acid. Subsequently, the reaction mixture was incubated at room temperature under dark conditions for $25 \mathrm{~min}$. The IAA concentration of each sample was measured at $530 \mathrm{~nm}$ using a UV-spectrometer. Each experiment was conducted three times.

\subsection{Descriptions of Study Area and Field Conditions}

The experimental sites of a jujube orchard were located $\left(35^{\circ} 84^{\prime} 69^{\prime \prime} \mathrm{N}, 128^{\circ} 80^{\prime} 40^{\prime \prime} \mathrm{E}\right)$ in Gyeongsan City, Gyeongbuk Province, Korea (Figure 1A). The study area in Gyeongsan City had a mean temperature of 14.8 and $14.5^{\circ} \mathrm{C}$ in 2019 and 2020, respectively. The annual precipitation at this site was 995.7 and $1307 \mathrm{~mm}$ in 2019 and 2020, respectively. The primary soil type in the experiment area was sandy loam.

In the jujube orchard, a rain shelter with transparent vinyl was installed above the tree crowns to prevent fruits from falling due to rain (Figure 1C). Jujube trees were approximately 50 years old. Their heights were pruned to an average of $4 \mathrm{~m}$. Their average 
diameter at breast height was $15 \mathrm{~cm}$ [5]. The experimental field was arranged using a rectangular plot design measuring $12 \mathrm{~m}$ wide and $20 \mathrm{~m}$ long with a distribution of 15 trees. The following two treatment groups were used in the field experiment: (1) control without B. licheniformis PR2 and (2) B. licheniformis PR2 inoculation (Figure 1B). There were two plots and a buffer ( $4 \mathrm{~m}$ wide $\times 20 \mathrm{~m}$ long) between plots (Figure 1B).

A total of $75 \mathrm{~mL}$ of B. licheniformis PR2 $\left(10^{9} \mathrm{CFU} / \mathrm{mL}\right)$ was inoculated into a $250 \mathrm{~L}$ pink broth (PB) (fertilizer, $3 \mathrm{~g} / \mathrm{L} ; \mathrm{MgSO}_{4} \cdot 7 \mathrm{H}_{2} \mathrm{O}, 0.2 \mathrm{~g} / \mathrm{L} ; \mathrm{KH}_{2} \mathrm{PO}_{4}, 0.2 \mathrm{~g} / \mathrm{L} ; \mathrm{NaCl}, 0.1 \mathrm{~g} / \mathrm{L}$; sucrose, $3 \mathrm{~g} / \mathrm{L}$; chitin, $0.6 \mathrm{~g} / \mathrm{L}$; yeast extract, $0.6 \mathrm{~g} / \mathrm{L}$ ) and cultured at $50{ }^{\circ} \mathrm{C}$ for 7 days. After the 7 days, it was diluted with tap water (1:2 v/v) and applied to the root rhizosphere 14 times over 2-3 weeks from April to October in 2019 and 2020, respectively. The bacterial culture was diluted with tap water and applied at a rate of $50 \mathrm{~L} /$ tree.

\subsection{Chlorophyll Content Analysis and Jujube Fruit Production}

In order to investigate the chlorophyll content and fruit rotting damage, fruit characteristics, and yield, three standard trees with similar crown size and flowering amount in May 2019 were selected in each treatment group. Chlorophyll content was measured once per month from June to September in 2019 and 2020, respectively, using a chlorophyll meter (SPAD-502 Plus; Minolta, Tokyo, Japan). To obtain the average chlorophyll content for each sample, the content in 25 leaves taken from all sides of the middle height of the tree was measured. The chlorophyll content was expressed as soil plant analysis development (SPAD) value.

To investigate fruit rotting damage and yield, all jujube fruits of three standard trees were harvested in each group in October 2019 and 2020, respectively. Jujube fruits were collected into plastic boxes. Healthy fruits and rotting fruits infected with fungal diseases were separated and weighed, respectively. Fruit rotting damage was measured using the following formula: fruit rotting rate $(\%)=[\beta /(\alpha+\beta)] \times 100$, where $\alpha$ was the weight of healthy fruits and $\beta$ was the weight of rotting fruits infected with fungal diseases. Healthy fruits were transported to a laboratory. Fruit characteristics, such as length and diameter, were measured for 30 randomly selected fruits from three standard trees of each group in 2019.

\subsection{Statistical Analysis}

Statistical analyses were performed to determine the effects of B. licheniformis PR2 on chlorophyll content, fruit rotting rate, fruit characteristics, and yields using SAS software, version 9.4 (SAS Institute Inc., Cary, NC, USA). Results are reported as mean \pm standard deviation based on Student's $t$-test with significance set at $p<0.05$.

\section{Results}

3.1. Inhibition of Fungal Pathogens by B. licheniformis PR2

\subsubsection{Changes in Chitinase Activity}

B. licheniformis PR2 growth increased slowly for 6 days and then increased rapidly 7 days after inoculation when the maximum growth of $50.8 \times 10^{7} \mathrm{CFU} / \mathrm{mL}$ was observed (Figure 2A). Subsequently, its growth rate quickly decreased until the end of the experiment.

Chitinase activity of B. licheniformis PR2 increased sharply for 2 days after inoculation to $72.5 \mathrm{unit} / \mathrm{mL}$, and then gradually to a maximum of value $92.4 \mathrm{unit} / \mathrm{mL}$ on 8 days after incubation (Figure 2B). 
A. Cell growth

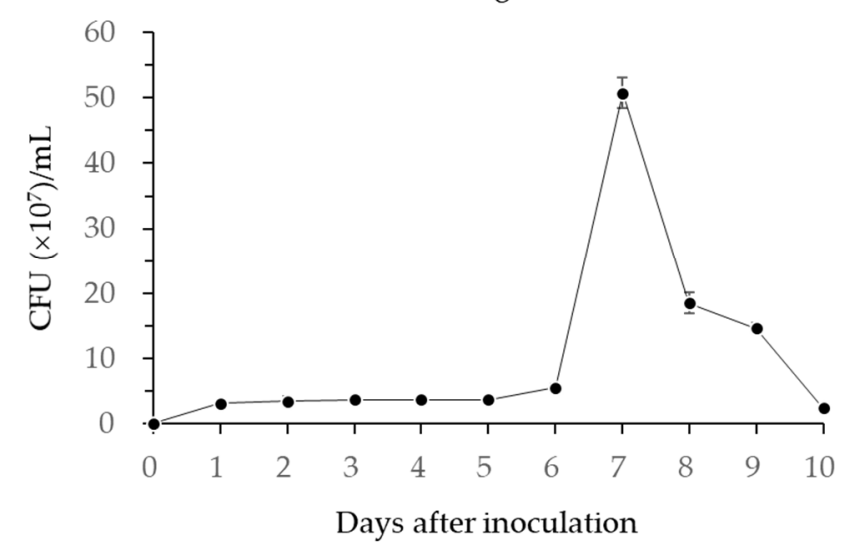

B. Chitinase activity

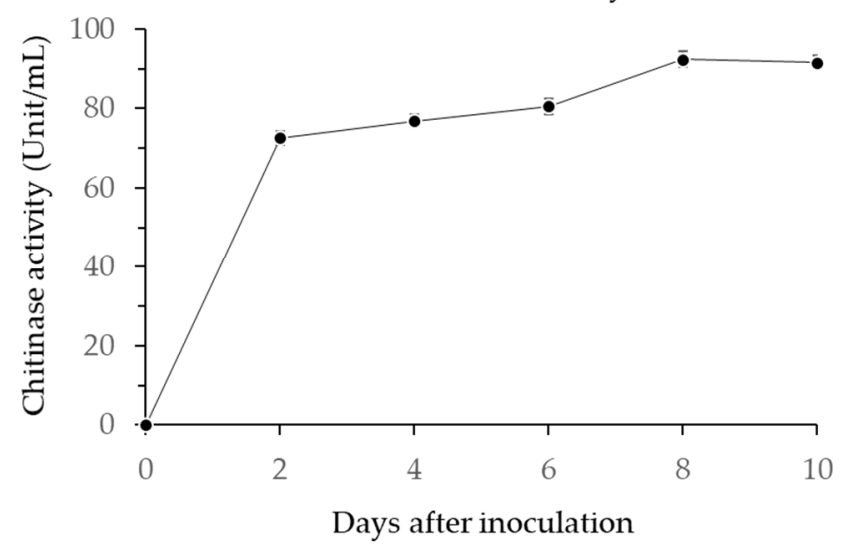

Figure 2. (A) Cell growth pattern and (B) chitinase activity of B. licheniformis PR2.

\subsubsection{Inhibition of Fungal Pathogen Growth by B. licheniformis PR2}

B. licheniformis PR2 inhibited the growth of each phytopathogenic fungus as follows: B. cinerea by $81.3 \%$, C. gloeosporioides by $60.1 \%$, and P. nicotianae by $67.0 \%$ (Figure 3A). In addition, light microscopic observations of hyphae of these phytopathogenic fungi indicated normal hyphal growth only in the control group (Figure 4A), but abnormal growths such as swelling and bulbous structures were observed in B. licheniformis PR2 in treated groups (Figure 4B).
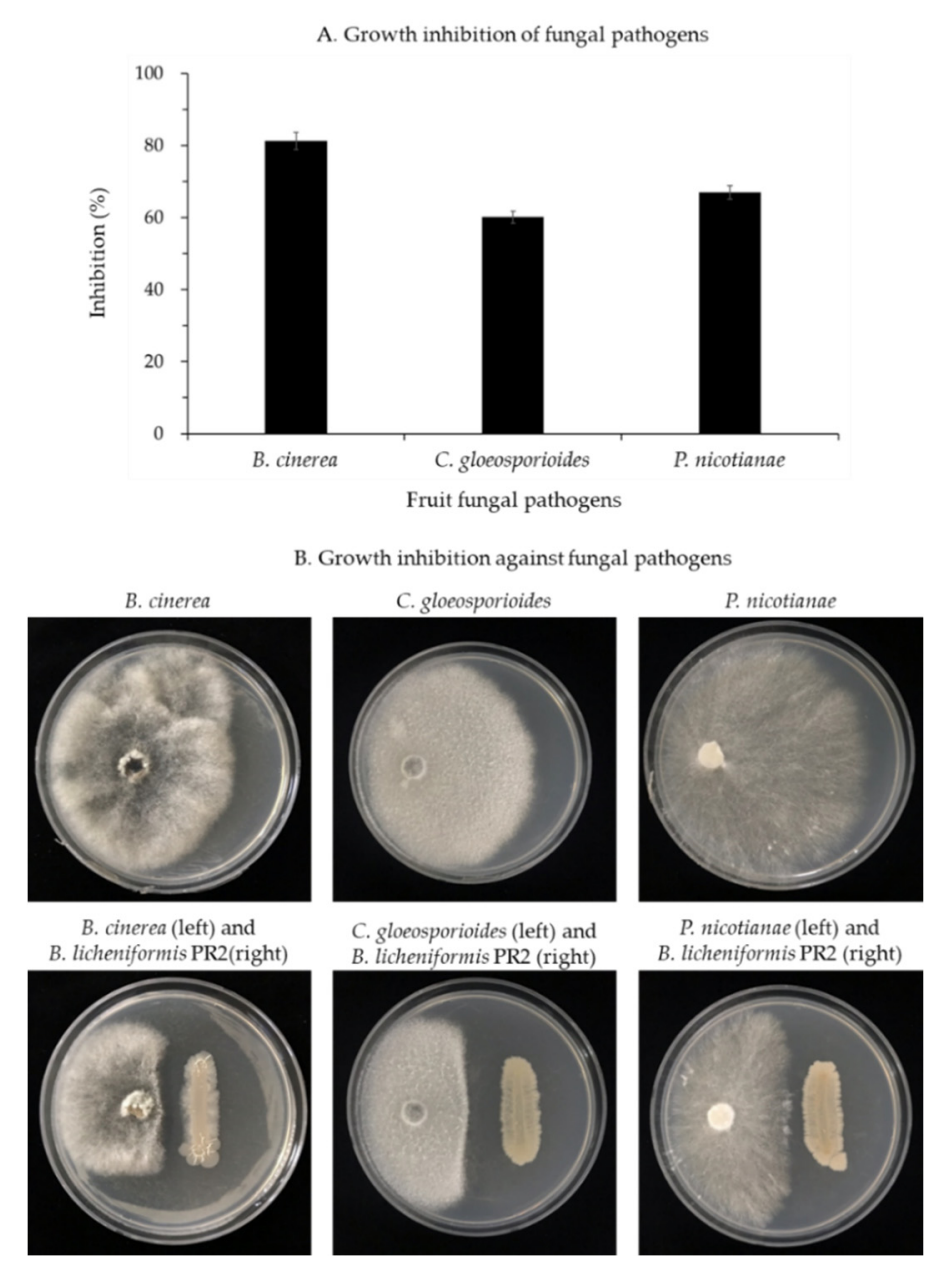

Figure 3. (A) Inhibition of mycelial growth and (B) antagonistic activity of B. licheniformis PR2 against fungal pathogenic B. cinerea, C. gloeosporioides, and P. nicotianae by the dual culture method. 
A. Control

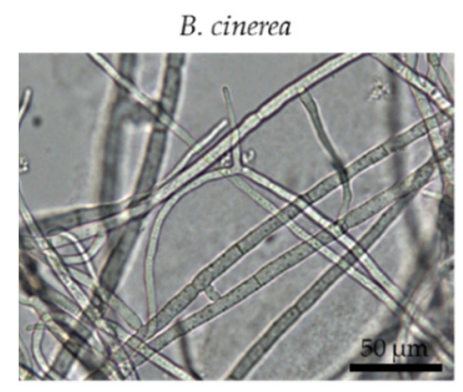

B. cinerea

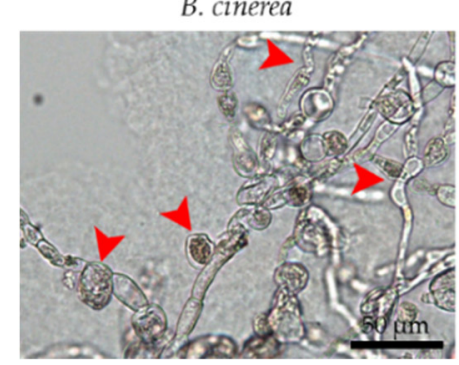

C. gloeosporioides

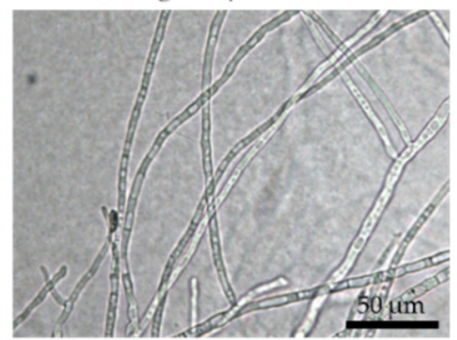

B. B. licheniformis PR2

C. gloeosporioides

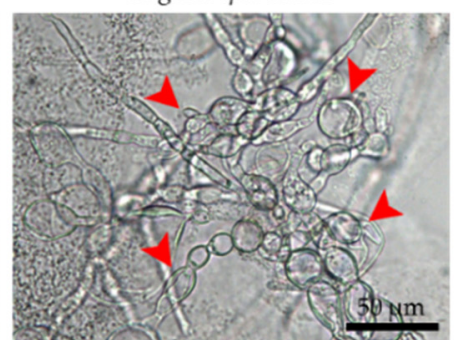

P. nicotianae

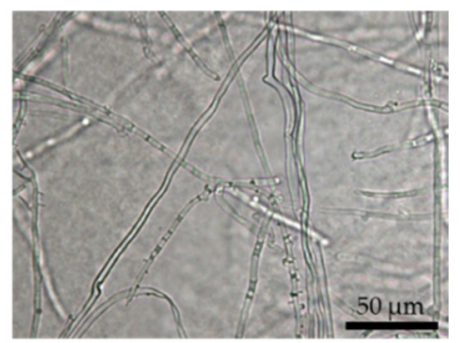

P. nicotianae

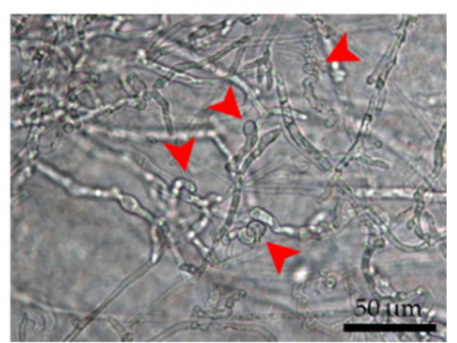

Figure 4. Light microscope images showing hyphal morphologies of B. cinerea, C. gloeosporioides, and P. nicotianae: (A) control and (B) treatment with B. licheniformis PR2. Arrows indicate abnormal structures caused by B. licheniformis PR2.

\subsection{Fruit Development by B. licheniformis PR2}

3.2.1. Auxin Production

B. licheniformis PR2 produced auxin (Figure 5). The IAA concentration increased on the 4th day of inoculation, eventually reaching a maximum value of $206.3 \mathrm{mg} / \mathrm{L}$ on the 7 th day (Figure 5). IAA concentration remained relatively stable from the 9 th to the 10 th day after inoculation.

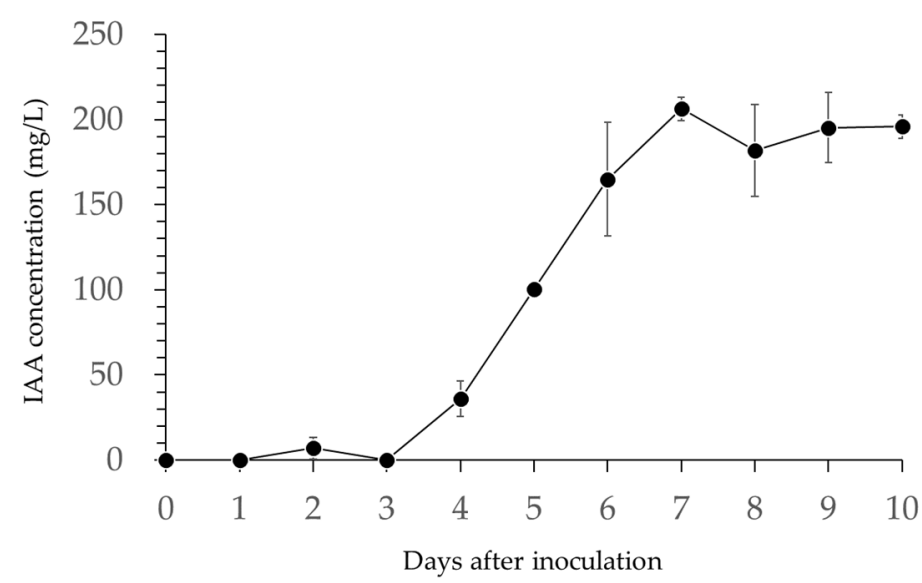

Figure 5. Changes in indole-3-acetic acid (IAA) production in $\mathrm{mg} / \mathrm{L}$ by B. licheniformis PR2, in vitro.

\subsubsection{Chlorophyll Content}

Inoculation with B. licheniformis PR2 increased chlorophyll contents in jujube tree leaves, leading to significantly higher contents in treated groups compared to the controls (Figure 6). Specifically, the average chlorophyll content in jujube trees inoculated with B. licheniformis PR2 was 36.8 units, approximately 1.2 times higher than the content in control trees, i.e., 30.4 units. 


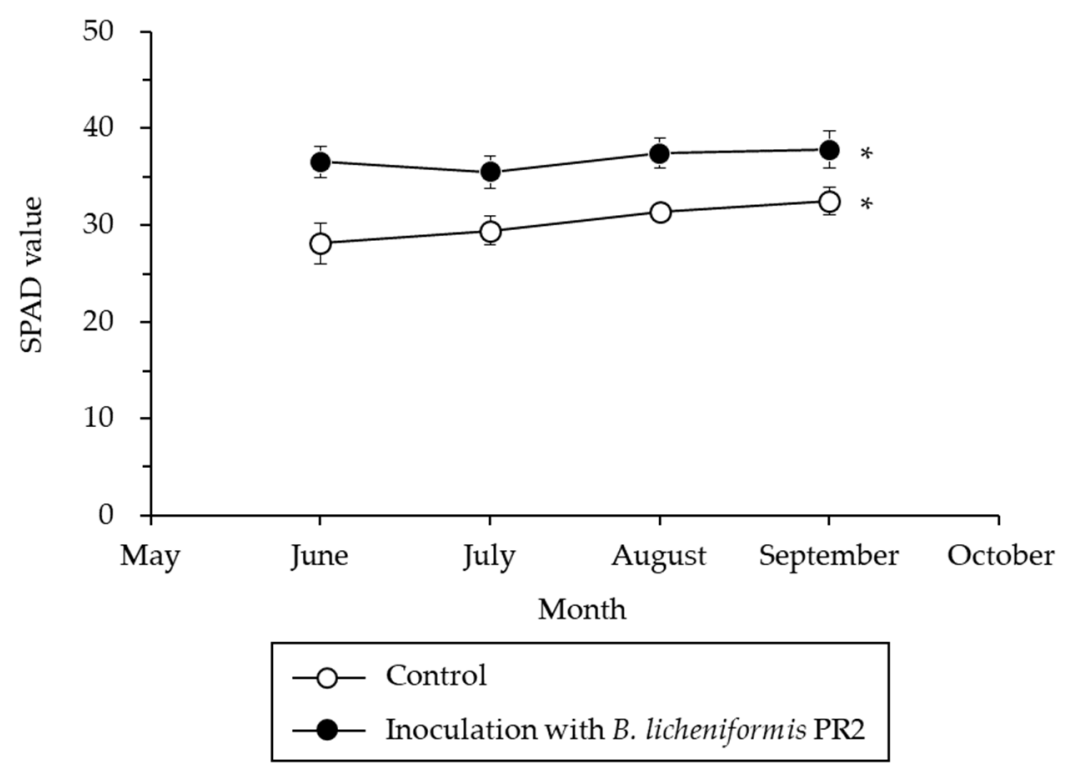

Figure 6. Average chlorophyll contents in jujube control trees and trees inoculated with B. licheniformis PR2 in 2019 and 2020. * indicates a significant difference at $p<0.05$.

\subsubsection{Fruit Rotting Rate, Characteristics, and Yields}

The rotting damage of jujube fruits appeared simultaneously in all treatments, limiting the yield of jujube fruits (Table 1). The average rotting damage rate in control fruits was $40.4 \%$, while the average fruit rotting rate in the treatment group was $13.3 \%$, which was 3.0 times lower than that control (Table 1). Among treated trees, the average length of jujube fruit inoculated with B. licheniformis PR2 was $38.5 \mathrm{~mm}, 1.2$ times longer than that of the control (33.1 mm; Table 1). The average diameter of fruits from treated trees was $29.9 \mathrm{~mm}$, 1.2 times larger than that of control fruits $(25.7 \mathrm{~mm})$. Regarding the fruit yield, trees treated with $B$. licheniformis PR2 produced an average of $17.9 \mathrm{~kg} /$ tree, which is 3.2 times higher than the control yield at $5.6 \mathrm{~kg} /$ tree (Table 1 ).

Table 1. Average jujube fruit rotting rate, length, diameter, and yield of jujube fruit in three standard trees with or without treatment with B. licheniformis PR2.

\begin{tabular}{ccccc}
\hline \multirow{2}{*}{ Treatment } & \multirow{2}{*}{$\begin{array}{c}\text { Fruit Rotting } \\
\text { Rate (\%) }\end{array}$} & \multicolumn{2}{c}{ Fruit Characteristics (mm) } & \multirow{2}{*}{ Fruit Yield } \\
\cline { 3 - 4 } & Length & Diameter & (kg/Tree) \\
\hline Control & $40.4 \pm 7.9 *$ & $33.1 \pm 3.9 *$ & $25.7 \pm 2.8^{*}$ & $5.6 \pm 2.9 *$ \\
Bacterial inoculation & $13.3 \pm 4.8^{*}$ & $38.5 \pm 2.5^{*}$ & $29.9 \pm 2.4^{*}$ & $17.9 \pm 8.2 *$ \\
\hline
\end{tabular}

${ }^{*}$ Difference between treatments significant at $p<0.05$ by Student's $t$-test. For fruit rotting rate and fruit yield values are means \pm standard deviation for 2019 and 2020 harvest seasons. Fruit characteristics were only analyzed in $2019(n=30)$.

\section{Discussion}

Recently, researchers have shown an increasing interest in using biocontrol agents to control fungal diseases in cultivated jujube orchards, which also leads to increased fruit production [5]. The use of PGPR to control phytopathogens and enhance plant growth has been widely reported over the years, with well-established mechanisms to explain the fascinating phenomenon by which they benefit the plants $[5,15-22,27,28]$. However, many biocontrol agents that produced good results under control laboratory conditions do not provide lasting solutions under complex field conditions. In the Republic of Korea, farmers demand strong antagonistic bacteria that can control fungal diseases and improve fruit production in jujube orchards. B. licheniformis PR2 used in this study secreted 92.4 unit/mL of chitinase (Figure 2B) and caused growth inhibition of fruit fungal pathogens, $B$. cinerea by $81.3 \%$, C. gloeosporioides by $60.1 \%$, and P. nicotianae by $67.0 \%$ (Figure 3 ). Based on 
the observed reduction in fruit rotting rate from $40.4 \%$ to $13.3 \%$ (Table 1). The present findings indicate that $B$. licheniformis PR2 has a strong antifungal activity and can be applied to effectively control major fruit fungal pathogens in jujube. Moreover, treatment with B. licheniformis PR2 increased jujube fruit production 3.2 times compared to the control group (Table 1). These findings indicate that $B$. licheniformis PR2 could be a successful PGPR that can be applied as a biocontrol control alternative to fungicides against major fruit fungal pathogens in jujube, reduce losses caused by fruit rotting damage, and also improve fruit production. Specifically, chitinases produced by B. licheniformis PR2, causes cell wall lysis of fungal pathogens and can inhibit phytopathogenic spore germination, which reduces fruit rotting incidence and severity [36].

Moreover, like most PGPR, B. licheniformis PR2 produced auxin (Figure 5) and increased chlorophyll content, which indicate the possibility of enhanced nutrient uptake that could have led to the observed increase in fruit production (Table 1) [16,29]. Basset Mia et al. [30] observed that when banana plants were inoculated with Bacillus sphaericus UPMB, the chlorophyll contents increased 1.3 times. Chlorophyll contents indicate potential photosynthetic activity. Thus, enhanced photosynthetic activity leads to improved fruit quality and size [16,29]. Similarly, in this study, treatment with B. licheniformis PR2 resulted in significantly improved jujube fruit quality characteristics (in terms of desired size and shape) and yields compared to tress in the control group (Table 1). The results of the current study also supported the observations of Medrano et al. [29], who reported that grapevine yield increased 2.2 times when photosynthetic activity was increased by $30 \%$. In addition, the secreted auxin (Figure 5 ) is known to act at the time of cell division after flowers are fertilized $[23,24,26]$. Hence, inoculation with B. licheniformis PR2 could have improved jujube fruit characteristics by accelerating crucial physiological processes, leading to enhanced productivity.

\section{Conclusions}

The results of the current study revealed that B. licheniformis PR2 secreted chitinase, which could have reduced the loss caused by fruit rotting damage, thereby improving fruit yield. In addition, $B$. licheniformis PR2 secreted auxin, which could have promoted cell division, nutrient uptake, and flower fertilization, leading to improved fruit quality (size and shape) in jujube.

Author Contributions: Conceptualization, J.-H.K. and Y.S.A.; methodology, J.-H.K., S.-J.W., J.-H.M., Y.-S.P., C.E.H.M. and Y.S.A.; formal analysis, J.-H.K. and C.E.H.M.; investigation, J.-H.K., S.-J.W., J.-H.M., Y.-S.P., U.L. and Y.S.A.; data curation, J.-H.K., S.-J.W. and Y.S.A.; writing-original draft preparation, J.-H.K. and Y.S.A.; writing-review and editing, J.-H.K., S.-J.W., H.B.A. and Y.S.A.; supervision, Y.S.A.; project administration, Y.S.A.; funding acquisition, Y.S.A. All authors have read and agreed to the published version of the manuscript.

Funding: This study was supported by the R\&D program for Forest Science Technology Projects (No. 2018122B10-1820-AB01 and No. 2020183C10-2022-AA02) funded by the Korea Forestry Promotion Institute. This research was also supported by a grant (No. 2018R1D1A1B07050052) from the National Research Foundation of Korea under the Basic Science Research Program.

Institutional Review Board Statement: Not applicable.

Informed Consent Statement: Not applicable.

Data Availability Statement: The data present in this study are available on request from the corresponding author. The data are not publicly available due to privacy.

Conflicts of Interest: The authors declare no conflict of interest.

\section{References}

1. Gao, Q.H.; Wu, C.S.; Wang, M. The jujube (Ziziphus jujuba Mill.) fruit: A review of current knowledge of fruit composition and health benefits. J. Agric. Food Chem. 2013, 61, 3351-3363. [CrossRef] [PubMed]

2. Pareek, S. Nutritional composition of jujube fruit. Emir. J. Food Agric. 2013, 25, 463-470. [CrossRef] 
3. Wang, B.; Huang, Q.; Venkitasamy, C.; Chai, H.; Gao, H.; Cheng, N.; Cao, W.; Lv, X.; Pan, Z. Changes in phenolic compounds and their antioxidant capacities in jujube (Ziziphus jujuba Miller) during three edible maturity stages. LWT Food Sci. Technol. 2016, 66, 56-62. [CrossRef]

4. Liu, M.J.; Zhao, Z.H. Germplasm resources and production of jujube in China. Acta Hortic. 2009, 840, 25-32. [CrossRef]

5. Kwon, J.-H.; Won, S.-J.; Moon, J.-H.; Kim, C.-W.; Ahn, Y.-S. Control of fungal diseases and increase in yields of a cultivated jujube fruit (Zizyphus jujuba Miller var. inermis Rehder) orchard by employing Lysobacter antibioticus HS124. Forests 2019, 10, 1146. [CrossRef]

6. Mirzaee, M.R. An overview of jujube (Zizyphus jujuba) diseases. Arch. Phytopathol. Plant Prot. 2014, 47, 82-89. [CrossRef]

7. Yang, C.; Hamel, C.; Vujanovic, V.; Gan, Y. Fungicide: Modes of action and possible impact on nontarget microorganisms. ISRN Ecol. 2011, 2011, 130289. [CrossRef]

8. Kookana, R.S.; Baskaran, S.; Naidu, R. Pesticide fate and behaviour in Australian soils in relation to contamination and management of soil and water: A review. Aust. J. Soil Res. 1998, 36, 715-764. [CrossRef]

9. Wightwick, A.; Allinson, G. Pesticide residues in Victorian waterways: A review. Australas. J. Ecotox. 2007, 13, 91-112.

10. Prusty, B.A.K. A book review on "Climate change and chemicals: Environmental and biological aspects". Curr. Sci. India 2011, $100,121-122$.

11. Komarek, M.; Cadkova, E.; Chrastny, V.; Bordas, F.; Bollinger, J.-C. Contamination of vineyard soils with fungicides: A review of environmental and toxicological aspects. Environ. Int. 2010, 36, 138-151. [CrossRef] [PubMed]

12. Wightwick, A.M.; Mollah, M.R.; Partington, D.L.; Allinson, G. Copper fungicide residues in Australian vineyard soils. J. Agric. Food Chem. 2008, 56, 2457-2464. [CrossRef] [PubMed]

13. Newman, P.; Jennings, I. Cities as Sustainable Ecosystems: Principles and Practices; Island Press: Washington, DC, USA, 2008; pp. 32-63.

14. Rezai, G.; Teng, P.K.; Mohamed, Z.; Shamsudin, M.N. Consumers' awareness and consumption intention towards green foods. Afr. J. Bus. Manag. 2012, 6, 4496-4503. [CrossRef]

15. Esitken, A.; Karlidag, H.; Ercisli, S.; Sahin, F. Effects of foliar application of Bacillus subtilis Osu-142 on the yield, growth and control of shot-hole disease (Coryneum blight) of apricot. Gartenbauwissenschaft 2002, 67, 139-142. Available online: https: / / www.pubhort.org/ejhs/2002/file_3710.pdf (accessed on 21 December 2020).

16. Glick, B.R. Plant growth-promoting bacteria: Mechanisms and applications. Scientifica 2012, 2012, 963401. [CrossRef] [PubMed]

17. Glick, B.R. The enhancement of plant growth by free-living bacteria. Can. J. Microbiol. 1995, 41, 109-117. [CrossRef]

18. Orhan, E.; Esitken, A.; Ercisli, S.; Turan, M.; Sahin, F. Effects of plant growth promoting rhizobacteria (PGPR) on yield, growth and nutrient contents in organically growing raspberry. Sci. Hortic. 2006, 111, 38-43. [CrossRef]

19. Karlidag, H.; Esitken, A.; Turan, M.; Sahin, F. Effects of root inoculation of plant growth promoting rhizobacteria (PGPR) on yield, growth and nutrient element contents of leaves of apple. Sci. Hortic. 2007, 114, 16-20. [CrossRef]

20. Ipek, M.; Pirlak, L.; Esitken, A.; Dönmez, M.F.; Turan, M.; Sahin, F. Plant growth-promoting rhizobacteria (PGPR) increase yield, growth and nutrition of strawberry under high-calcareous soil conditions. J. Plant Nutr. 2014, 37, 990-1001. [CrossRef]

21. Park, H.-G.; Jeong, M.-H.; Ahn, Y.-S. Inoculation with Bacillus licheniformis MH48 to improve Camellia japonica seedling development in coastal lands. Turk. J. Agric. For. 2017, 41, 381-388. [CrossRef]

22. Park, H.-G.; Lee, Y.-S.; Kim, K.-Y.; Park, Y.-S.; Park, K.-H.; Han, T.-H.; Park, C.-M.; Ahn, Y.S. Inoculation with Bacillus licheniformis MH48 promotes nutrient uptake in seedlings of the ornamental plant Camellia japonica grown in Korean reclaimed coastal land. Hortic. Sci. Technol. 2017, 35, 11-20. [CrossRef]

23. Srivastava, A.; Handa, A.K. Hormonal regulation of tomato fruit development: A molecular perspective. J. Plant Growth Regul. 2005, 24, 67-82. [CrossRef]

24. Gravel, V.; Antoun, H.; Tweddell, R.J. Growth stimulation and fruit yield improvement of greenhouse tomato plants by inoculation with Pseudomonas putida or Trichoderma atroviride: Possible role of indole acetic acid (IAA). Soil Biol. Biochem. 2007, 39, 1968-1977. [CrossRef]

25. Hussain, A.; Hasnain, S. Interactions of bacterial cytokinins and IAA in the rhizosphere may alter phytostimulatory efficiency of rhizobacteria. World J. Microbiol. Biotechnol. 2011, 27, 2645-2654. [CrossRef]

26. Liu, D.-J.; Chen, J.-Y.; Lu, W.-J. Expression and regulation of the early auxin-responsive Aux/IAA genes during strawberry fruit development. Mol. Biol. Rep. 2011, 38, 1187-1193. [CrossRef] [PubMed]

27. Won, S.-J.; Choub, V.; Kwon, J.-H.; Kim, D.-H.; Ahn, Y.-S. The control of fusarium root rot and development of coastal pine (Pinus thunbergii Parl.) seedlings in a container nursery by use of Bacillus licheniformis MH48. Forests 2019, 10, 6. [CrossRef]

28. Won, S.-J.; Kwon, J.-H.; Kim, D.-H.; Ahn, Y.-S. The effect of Bacillus licheniformis MH48 on control of foliar fungal diseases and growth promotion of Camellia oleifera seedlings in the coastal reclaimed land of Korea. Pathogens 2019, 8, 6. [CrossRef]

29. Medrano, H.; Escalona, J.M.; Cifre, J.; Bota, J.; Flexas, J. A ten-year study on the physiology of two Spanish grapevine cultivars under field conditions: Effects of water availability from leaf photosynthesis to grape yield and quality. Funct. Plant Biol. 2003, 30, 607-619. [CrossRef] [PubMed]

30. Baset Mia, M.A.; Shamsuddin, Z.H.; Wahab, Z.; Marziah, M. Effect of plant growth promoting rhizobacterial (PGPR) inoculation on growth and nitrogen incorporation of tissue-cultured Musa plantlets under nitrogen-free hydroponics condition. Aust. J. Crop Sci. 2010, 4, 85-90. 
31. Ramamoorthy, V.; Viswanathan, R.; Raguchander, T.; Prakasam, V.; Samiyappan, R. Induction of systemic resistance by plant growth promoting rhizobacteria in crop plants against pests and diseases. Crop Prot. 2001, 20, 1-11. [CrossRef]

32. Vivekananthan, R.; Ravi, M.; Ramanathan, A.; Samiyappan, R. Lytic enzymes induced by Pseudomonas fluorescens and other biocontrol organisms mediate defence against the anthracnose pathogen in mango. World J. Microbiol. Biotechnol. 2004, 20, 235-244. [CrossRef]

33. Arikan, S.; Pirlak, L. Effects of plant growth promoting rhizobacteria (PGPR) on growth, yield and fruit quality of sour cherry (Prunus cerasus L.). Erwerbs-Obstbau 2016, 58, 221-226. [CrossRef]

34. Lingappa, Y.; Lockwood, J. Chitin media for selective isolation and culture of actinomycetes. Phytopathology 1962, 52, 317-323.

35. Rahman, A.; Sitepu, I.R.; Tang, S.-Y.; Hashidoko, Y. Salkowski's reagent test as a primary screening index for functionalities of rhizobacteria isolated from wild dipterocarp saplings growing naturally on medium-strongly acidic tropical peat soil. Biosci. Biotechnol. Biochem. 2010, 74, 2202-2208. [CrossRef]

36. Gomaa, E.Z. Chitinase production by Bacillus thuringiensis and Bacillus licheniformis: Their potential in antifungal biocontrol. J. Microbiol. 2012, 50, 103-111. [CrossRef] 